der bearbeiteten Materie bereits Vertrauten wird damit eine einfache und übersichtliche Handhabung gewährleistet. In Anbetracht des Werktitels, der allgemein von "Ausländern" spricht, dürfte man einige kurze Betrachtungen explizit in Bezug auf Ubersee- und insbesondere Dritte-Welt-Ausländer erwartet haben. Zwar gelten die meisten aufgeführten Abkommen nur für die Familien von Vertragsstaaten; dennoch wäre eine entsprechende Erörterung im Rahmen der EMRK, die in ihren Artikeln 8 und 14 jedermann, und mithin auch Dritte-Welt-Ausländer in ihren Schutzbereich einbezieht, wünschenswert gewesen. Die allgemeinen Anmerkungen über territoriale Einschränkungen in Bezug auf überseeische Gebiete genügen für das Gesamtwerk jedenfalls nicht.

Bedenkt man allerdings, wie gering und durchweg umstritten die Rechtsgewährung hinsichtlich des Familiennachzugs von Dritte-Welt-Ausländern ausfällt und überträgt man die Erörterungen zu Art. 8 und 14 EMRK namentlich auch auf diese Ausländergruppe, so kann diese Lücke nicht den positiven Gesamteindruck des vorliegenden Werkes beeinträchtigen.

Thomas Schließke

\title{
Shabtei Rosenne
}

\section{Practice and Methods of International Law}

Oceana Publications, New York, 1984, U.S. $\$ 25.00$

The title of the latest book by the eminent Israeli lawyer Shabtai Rosenne suggests that the book would concern the theoretical and methodological aspects of international law. In fact it is rather a guide through the system of contemporary international law. It ought to facilitate orientation in bibliographies and in the system of international law; for this purpose the author proposes and promotes the introduction of a unified system of citation of sources of international law in the formal meaning of this word. In no case can the book be treated as a handbook of international law even if it reflects the autor's considerations and personal reflections on contemporary international law.

The first chapter of the book clearly is of an introductory character while the following ones concern the sources of international law, both traditional, universally recognized, and those whose normative character is sometimes denied. The work is completed by several annexes.

The introduction contains a brief survey of fundamental notions of international law. The author emphasizes especially that international law is quite different from municipal law because of the lack of a central legislator - it is the law of coordination, not the law of subordination. Of course, this remark is clear and correct; it can be easily identified in the process creating norms of international law - even if the techniques of drafting legal texts, the system of values and fundamental principles and guidelines of both legal 
systems are the same. According to Mr. Rosenne, international law is created by the very same subjects which also apply it (this is a simplification because the author also recognizes the existence of entities possessing a international legal personality which do not take part in the international legislative process). Subsequently, Mr. Rosenne considers briefly the problems of relations between public international law and private international law (conflict rules), as well as the relations between international law and municipal law - the most important reflections concern the concepts of transnational law and ius cogens. Mr. Rosenne emphasizes the problem which is normally omitted by other writers: the norms of ius cogens have not been codified in any instrument and no international legal act contains the exemplification of such norms. Mr. Rosenne declares himself to be the antagonist of the application of analogy in international law (as e. g. Dr. Anzilotti and J. Strupp). The final part of the indroduction contains a review of principal encyclopaedias and dictionaries of international law with the proposal of unifying the system of citation of literature and international legal documents.

The following chapter presents international treaties in their quality as sources of international law. This consideration is based on the Vienna Convention on the Law of Treaties of 1969; the author does not, however, analyse the substantive provisions of the convention but limits himself to indicating the titles of respective chapters of the Convention and their contents. He considered in more detail only those questions which in his opinion are of practical importance to persons referring to the documents (such as e. g., reservations to treaties, interpretation of multilingual treaties, the practical importance of final acts of international codificatory conferences, travaux préparatoires etc.). The position of Professor Rosenne regarding problems of customary law is very interesting. He does not construct a hierarchy of sources of international law, even if in practice such a hierarchy exists and is strictly connected with the degree of concretization of international legal norms contained in respective sources. He accentuates one question only: the relation between customary and conventional international law. The author's reflection concentrates on two levels: that of the 1969 Vienna Convention (in particular of its article 38 - which is often quoted in this context - and article 43, concerning directly the relations between international treaty law and customary law emerging from that foundation) and that of codificatory conferences. It is also interesting that Mr. Rosenne, considering the elements of practice constituting custom, underlines the limited importance of treaty practice and especially the creative force of bilateral agreements; he adopts the same attitude towards the acts of international organizations (the formation of space law being a classical example). Finally, Mr. Rosenne expresses the interesting opinion that the rôle of codifications has grown since the newly independent states declared themselves not to be bound by existing customary law. The subsequent chapter concerns the importance of judicial practice in the formation of international law. The author, although educated in the common law system, does not recognize directly the precedent rôle of judgements, neither of international nor municipal courts, in the formation of international law, even if the Anglo-American doctrine strongly emphasizes the contribution of judicial practice to the formation of interna- 
tional law. The most interesting part of this chapter concerns the fundamental problems of international procedural law in its comparative aspect.

The final parts of the book concern the legal quality of resolutions (Mr. Rosenne denies the existence of direct binding force of such resolutions) and of doctrine in the formation of international law.

Władyslaw Czapliński

\section{Paul Sieghart}

\section{The International Law of Human Rights}

Oxford University Press, 1984, 117.50

The problem of international legal protection of human rights has recently been very popular among international lawyers, and the number of publications in this field still increases. These publications are of very varying character: some of them concern special questions while others are relatively complex and illustrate the progressive development in the field of international law of human rights. No author would be able to refer to all works concerning this problem, inter alia because of language difficulties and Paul Sieghart has not had such ambitions. He has tried to present the actual situation in the field of international protection of human rights, taking into account norms and solutions adopted in international instruments on human rights.

The author has divided his work into four parts. The first one is of an introductory character and concerns the development of the concept of human rights in international and municipal law, the origin of respective human rights acts in international law and, finally, some fundamental problems of the law of treaties and of the application of international law within the internal legal orders. This part of the work seems not to be necessary and certainly it is not exhaustive. For example, the author touched briefly the problem of so-called self-executing treaties in international law (at p. 41) - yet it would be useful to consider to what extent human rights instruments are and could be self-executing. In my opinion human rights treaties seldom are self-executing and normally require transformation - this is one important reason for non-implementation of international legal obligations in this field. The respective states invoke a raison d'état to justify non-compliance with human rights acts; they maintain that states only, non individuals, are the subjects of international law and according to the principle of state sovereignty they preserve full freedom of action in internal affairs. Those assertions have been affirmed in several human rights acts, including the two Covenants of 1966. Finally it must be pointed out that some important problems have been totally omitted by the author: one may mention here the problems of universalism and regionalism in human rights (especially the alleged reurocentrism`) which seem to be extremely important and 